\title{
Salmonellosis in layer chickens: pathological features and isolation of bacteria from ovaries and inner content of laid eggs
}

\author{
A. K. Saha, M. A Sufian, M. I. Hossain and M. M. Hossain \\ Department of Pathology, Faculty of Veterinary Science, Bangladesh Agricultural University, Mymensingh-2202, \\ Bangladesh. E-mail: mmhossain04@yahoo.com.au
}

\begin{abstract}
We isolated and identified Salmonella organisms from ovaries of dead layer birds and from inner content of laid eggs of different poultry farms. The thirty eight ovarian swabs for bacteriology, visceral organs (liver, lung, spleen, egg follicles and intestine) of 38 dead birds for pathological study from 15 layer farms and 45 laid eggs (5 eggs/farm) from reported 9 Salmonella infected farms constituted samples of the study. Samples were subjected to isolation and identification of the causal agent followed by gross and histopathological study of the affected visceral organs. Seventeen of 38 ovarian swabs (44.7\%) were Salmonella positive. The percentage of Salmonella Gallinarum, Salmonella Pullorum and paratyphoid causing Salmonella were $70.6 \%, 17.6 \%$ \& 11.8\%, respectively. About 53\% livers of Salmonella affected birds were enlarged, congested, friable and bronze coloured with white necrotic foci. About 59\% egg follicles were congested, hemorrhagic, discoloured with stalk formation and $70.6 \%$ intestines showed hemorrhagic to catarrhal enteritis. At histopathology, $76.5 \%$ livers were congested with formation of multifocal nodules and $82.4 \%$ egg follicles were congested with huge leukocytic infiltration. Infiltration of heterophils in intestinal mucosa was found in $47.1 \%$ cases. Four Salmonella isolates were found from 9 laid egg samples (5 eggs content comprised as 1 sample) and isolation rate was $44.4 \%$ reporting transovarian transmission in poultry Salmonellosis.
\end{abstract}

Keywords: Histopathology, Laid eggs, Layer, Salmonellosis

\section{Introduction}

Poultry is essential to the national economy of Bangladesh and the welfare of human beings. Several constraints such as the diseases, poor husbandry, low productivity and shortage of feed affect the optimal performance of this industry in Bangladesh (Haque et al., 1991). Salmonellosis in poultry causes heavy economic loss through mortality and reduced production (Khan et al., 1998). With great expansion of poultry rearing and farming, pullorum disease and fowl typhoid have become wide spread problem in Bangladesh (Rahman et al., 1997). Age wise prevalence of avian Salmonellosis showed highest infection rate in adult layers (53.25\%) in comparison to brooding (14.55\%), growing (16.10\%) and pullet (16.10\%) (Rahman et al., 2004).

Salmonella are Gram negative, short plump shaped rods, non-sporeforming, non- capsulated, aerobic and facultative anaerobic organisms and classified under the family Enterobacteriaceae (OIE Manual, 2006). More than 2300 serotypes of Salmonella have been identified, only about $10 \%$ of these have been isolated from poultry (Gast, 1997). Chickens are the natural hosts for both S. Pullorum and S. Gallinarum (Snoeyenbos, 1991). Pullorum disease is usually confined to the first 2-3 weeks of age and occasionally occurs in adults (Shivaprashad, 1997). Fowl typhoid is frequently referred to as a disease of adult birds and there are also reports of high mortality in young chicks (Christensen et al., 1992). The epidemiology of fowl typhoid and pullorum disease in poultry, particularly with regard to transmission from one generation to the next are known to be closely associated with infected eggs (Wigley et al., 2001). Contaminated eggs produced by infected laying hens are thought to be one of the main sources of human infection with Salmonella Enteritidis (Humphrey et al., 1989). Eggs may become contaminated with Salmonella in two main ways: (i) Salmonella may silently infect the ovaries of apparently healthy hens and contaminate the eggs before the shells are formed. (ii) Salmonella infected bird droppings contain Salmonella that can contaminate the outer egg shells and may penetrate when crack the shell (Deryck and Pattron, 2004) Therefore, the present study was designed to isolate and identify Salmonella organism from ovaries of dead layer birds and inner content of laid eggs of different poultry farms at Mymensingh district as well as to study the pathology of different organs of Salmonella infected layer birds. 


\section{Materials and Methods}

Experimental area: The study was conducted during the period from January to August 2010 at Mymensingh district. A total of 15 layer farms which contained 29,800 birds with no history of using Salmonella vaccine were selected for the study.

\section{Isolation and identification of Salmonella organism from ovarian swabs of dead birds}

Collection of samples: A total of 38 ovarian swab samples were collected from the same flock along with the necropsy study. All the ovarian swabs were collected in test tubes containing $10 \mathrm{ml}$ tetrathionate broth (TTB) and $200 \mu \mathrm{l}$ of iodine-iodide solution was added in each test tube just before the collection of swab samples according to methods described elsewhere (Haider et al., 2003).

Cultural media: After overnight incubation in TTB, all the samples were primarily cultured in Nutrient agar and then subcultured in the Salmonella-Shigella (SS) agar, Triple sugar iron (TSI) agar, Brilliant green agar (BGA), Eosine methylene blue (EMB) agar (Haider et al., 2003).

Morphological characterization: The presumptive colonies of Salmonella in different media were characterized microscopically using Gram's stain.

Carbohydrate fermentation test and biochemical test: Five basic sugars such as glucose, sucrose, lactose, mannitol and maltose were used for sugar fermentation test.

Biochemical test: It included MR test, VP test, indole test and dulcitol fermentation test (Merchant and Packer, 1967; Haider et al., 2003).

Motility test: Motility test was performed for the separation of motile and non-motile Salmonella according to the method described elsewhere (Haider et al., 2003).

Pathological studies: During the whole period of study, postmortem examinations of 38 dead birds were performed from the representative selected 15 layer farms. Gross pathological changes at necropsy were carefully observed and recorded. The tissues of different organs were preserved in $10 \%$ neutral buffered formalin for histopathological studies. The tissues were trimmed with $1.5 \times 1 \mathrm{~cm}$ size, washed overnight in running tap water, dehydration in ascending grades of alcohol, cleaning in chloroform, blocking in paraffin and sectioned with microtome at 6 micron thickness. The sections were stained with routine hematoxylin and eosin staining (Luna, 1968) and finally the sections were studied with light microscope.

\section{Isolation of Salmonella sp from inner content of laid eggs}

This test was performed by following the method described by Poppe et al. (1992) and Haider (2009). Total 45 eggs were collected from 9 farms (5 eggs $/ 9$ farms) followed by washing and disinfection of egg surface by $70 \%$ ethanol. Manually homogenization of pooled egg contents was performed by using stirrer. Incubation of homogenized egg contents was done with pre-enrichment media (BPW) at $37^{\circ} \mathrm{C}$ temperature as a standard proportion of 1:10 fold dilution for 48 hours followed by incubation in selective enrichment media (SRV) at $37^{\circ} \mathrm{C}$ temperature as a proportion of $1: 10$ fold dilution for 24 hours. Then plating was performed onto selective agar media (BGA, SS, TSI \& EMB agar).

\section{Results and Discussion}

Cultural prevalence with isolation and identification of Salmonella organism

In the present study, all 17 isolates of Salmonella organisms showed different cultural characteristics in different media. These were turbidity in TTB broth and isolates showed slightly yellowish white color colonies in BGA, slightly grayish color colonies in SS agar, black color colony in TSI agar, gray white colony in nutrient agar, pinkish in EMB agar and pale color colonies in Mc Conkey's agar. These findings of present study corresponded with the results of Old (1990); Yuno et al. (1995); Sharma and Katok (1996); Sujatha et al. (2003); Perez et al. (2004 ); Rybolt et al. (2005) and Ahmed et al. (2008). 


\section{Identification (Gram's staining)}

In Gram's staining, all the isolates in the present investigation revealed gram-negative, rod shaped appearance and arranged in single. Chains of more than two bacilli were normally absent. Freeman (1985) described the morphology of the isolated Salmonella bacteria as small rod shaped, gram negative, single or paired in arrangement by Gram's staining which supported the findings of the present study. Similar morphological findings of Salmonella were also supported by other investigators (Islam et al., 2006; Ahmed et al., 2008).

\section{Motility test}

In motility test, 15 Salmonella isolates were identified as non-motile and 2 Salmonella were identified as motile and percentage of motile Salmonella was $11.8 \%$. These results were similar to Christensen et al. (1996) and they found $11.69 \%$ motile Salmonella. On the other hand, there was small variation with the results of Buxton and Fraser (1977) which may be due to the difference in managemental condition of farms. The results of the present study were also supported by other investigators (Shane, 1989; Pomeroy and Nagaraja, 1991; Islam et al., 2006; Ahmed et al., 2008; who found 13.71\%, 13.5\%, 12.82\%, and $13.5 \%$ motile Salmonella, respectively).

\section{Carbohydrate fermentation and different biochemical tests}

In the present investigation, among 17 isolates, 70.6\% (12) were Salmonella Gallinarum, $17.6 \%$ (03) were Salmonella Pullorum and $11.8 \%$ (02) isolates were identified as paratyphoid causing Salmonella. The findings of present study corresponded with Buxton and Fraser (1977); Shane (1989); Pomeroy and Nagaraja (1991) and Christensen et al. (1996).

\section{Pathological studies}

Gross pathology: In present study, the gross lesions of 17 Salmonella infected layer birds were variable. During necropsy, $53 \%$ livers were friable, bronze discoloration with white focal necrosis (Fig. 1). A total of $47.1 \%$ livers were congested and enlarged. About 59\% egg follicles were congested, hemorrhagic and discolored with stalk formation while $41.2 \%$ egg follicles were mildly congested and hemorrhagic (Table 1; Fig. 2). A total of $70.6 \%$ intestines were hemorrhagic to catarrhal enteritis while $29.4 \%$ only hemorrhagic and congested. About $64.7 \%$ lungs were severely congested and pneumonic while $35.3 \%$ lung showed mild congestion. About $47.1 \%$ spleens were enlarged and discolored. Similar findings with intensity of the severity of lesions in different organs were described by many investigators (Chishti et al., 1985; Khan et al., 1998; Hafeji et al., 2001; Habib-ur-Rehman et al., 2003; Beyaz and Kutsal, 2003; Goswami et al., 2003; Hossain et al., 2003; Prasanna and Paliwal, 2003; Islam et al., 2006; Deshmukh et al., 2007).

Histopathology: Only 17 Salmonella positive dead bird tissues of different organs were selected for histopathology. Table 2 describes the histopathological findings of different organs. In histopathological investigation, all the tissues of different organs of 17 layer birds did not evoke similar kinds of lesions. A total of $76.5 \%$ livers were congested and formed multifocal nodules with coagulation necrosis while remaining 23.5\% liver showed hepatitis (Fig. 4). Besides, $76.5 \%$ lungs were severely congested and hemorrhagic and $23.5 \%$ lung showed inflammatory cells in alveoli and bronchi (Fig. 3). Infiltration of heterophils and lymphocytes in the mucosa of intestines were found in $47.1 \%$ cases. Sever lymphocytic depletion and focal necrosis in the spleen was found in $53 \%$ birds (Fig. 5). Whereas, about $82.4 \%$ egg follicles was markedly congested and showed huge leukocytic infiltration (Fig. 6). The microscopic lesions recorded in the present investigation were almost similar to the lesions described by other authors (Chishti et al., 1985; Calnek et al., 1991; Khan et al., 1998; Kinde et al., 2000; Hafeji et al., 2001; Prasanna and Paliwal, 2003; Holt et al., 2006; Msoffe et al., 2006). 
Table 1. Gross pathological findings of Salmonella affected birds of different layer farms

\begin{tabular}{|c|c|c|c|c|c|c|c|c|c|c|c|}
\hline \multirow[b]{2}{*}{ Lesions } & \multicolumn{9}{|c|}{ Infected farm no. } & \multirow[b]{2}{*}{$\begin{array}{l}\text { Total } \\
\mathrm{N}=17\end{array}$} & \multirow[b]{2}{*}{$\%$} \\
\hline & $\begin{array}{c}\mathrm{F}-1 \\
(\mathrm{n}=3)\end{array}$ & $\begin{array}{c}\mathrm{F}-2 \\
(\mathrm{n}=2)\end{array}$ & $\begin{array}{c}F-5 \\
(n=3)\end{array}$ & $\begin{array}{c}F-6 \\
(n=2)\end{array}$ & $\begin{array}{c}\mathrm{F}-8 \\
(\mathrm{n}=1)\end{array}$ & $\begin{array}{l}\mathrm{F}-10 \\
(\mathrm{n}=1)\end{array}$ & $\begin{array}{l}\mathrm{F}-11 \\
(\mathrm{n}=2)\end{array}$ & $\begin{array}{c}\text { F-13 } \\
(n=1)\end{array}$ & $\begin{array}{c}\mathrm{F}-14 \\
(\mathrm{n}=2)\end{array}$ & & \\
\hline $\begin{array}{l}\text { Friable, bronze discoloration liver } \\
\text { with white focal necrosis }\end{array}$ & + & + & - & - & + & + & - & - & + & 9 & 53.0 \\
\hline Congested and enlarged liver & - & - & + & + & - & - & + & + & - & 8 & 47.1 \\
\hline $\begin{array}{l}\text { Congested haemorrhagic, and } \\
\text { discolored egg follicles with stalk } \\
\text { formation }\end{array}$ & + & + & - & + & + & + & - & + & - & 10 & 59.0 \\
\hline $\begin{array}{l}\text { Mild congested and } \\
\text { haemorrhagic egg follicles }\end{array}$ & - & - & + & - & - & - & + & - & + & 7 & 41.2 \\
\hline $\begin{array}{l}\text { Haemorrhagic to catarrhal } \\
\text { enteritis }\end{array}$ & + & + & + & - & + & + & - & - & + & 12 & 70.6 \\
\hline $\begin{array}{l}\text { Congested and haemorrhagic } \\
\text { intestine }\end{array}$ & - & - & - & + & - & - & + & + & - & 5 & 29.4 \\
\hline $\begin{array}{l}\text { Severely congested and } \\
\text { pneumonic lung }\end{array}$ & + & + & + & - & - & + & - & - & + & 11 & 64.7 \\
\hline Mild congested lung & - & - & - & + & + & - & + & + & - & 6 & 35.3 \\
\hline Enlarged with discolored spleen & + & + & - & - & - & + & - & - & + & 8 & 47.1 \\
\hline
\end{tabular}

"+"present, "-"absent and "n"= No. of positive bird / farm and F= Farm

Table 2. Histopathological findings of Salmonella affected tissues from different farm

\begin{tabular}{|c|c|c|c|c|c|c|c|c|c|c|c|}
\hline \multirow[b]{2}{*}{ Lesions } & \multicolumn{9}{|c|}{ Infected farm no. } & \multirow[b]{2}{*}{$\begin{array}{l}\text { Total } \\
\mathrm{N}=17\end{array}$} & \multirow[b]{2}{*}{$\%$} \\
\hline & $\begin{array}{c}\mathrm{F}-1 \\
(\mathrm{n}=3)\end{array}$ & $\begin{array}{c}\mathrm{F}-2 \\
(\mathrm{n}=2)\end{array}$ & $\begin{array}{c}\mathrm{F}-5 \\
(\mathrm{n}=3)\end{array}$ & $\begin{array}{c}\mathrm{F}-6 \\
(\mathrm{n}=2)\end{array}$ & $\begin{array}{c}\mathrm{F}-8 \\
(\mathrm{n}=1)\end{array}$ & $\begin{array}{l}\mathrm{F}-10 \\
(\mathrm{n}=1)\end{array}$ & $\begin{array}{l}\mathrm{F}-11 \\
(\mathrm{n}=2)\end{array}$ & $\begin{array}{l}\mathrm{F}-13 \\
(\mathrm{n}=1)\end{array}$ & $\begin{array}{l}\mathrm{F}-14 \\
(\mathrm{n}=2)\end{array}$ & & \\
\hline $\begin{array}{l}\text { Congestion and multifocal } \\
\text { nodule formation in liver }\end{array}$ & + & + & + & + & - & + & - & - & + & 13 & 76.5 \\
\hline $\begin{array}{l}\text { Hepatitis and infiltration of } \\
\text { inflammatory cells }\end{array}$ & - & - & - & - & + & - & + & + & - & 4 & 23.5 \\
\hline $\begin{array}{l}\text { Marked congestion and } \\
\text { leukocytic infiltration in egg } \\
\text { follicles }\end{array}$ & + & + & + & + & - & + & - & + & + & 14 & 82.4 \\
\hline $\begin{array}{l}\text { Infiltration of heterophils and } \\
\text { lymphocyte in the mucosa of } \\
\text { intestine }\end{array}$ & + & + & - & - & + & - & - & - & + & 8 & 47.1 \\
\hline $\begin{array}{l}\text { Severely congested and } \\
\text { hemorrhagic lung }\end{array}$ & + & + & - & + & + & - & + & + & + & 13 & 76.5 \\
\hline $\begin{array}{l}\text { Inflammatory cells in the alveoli } \\
\text { and bronchus }\end{array}$ & & & + & & & + & & & & 4 & 23.5 \\
\hline $\begin{array}{l}\text { Severely lymphocytic depletion } \\
\text { and focal necrosis in the spleen }\end{array}$ & + & + & - & + & + & - & - & + & - & 9 & 53.0 \\
\hline
\end{tabular}

"+"present, "-"absent and "n"= No. of positive bird / farm and F= Farm

\section{Isolation and cultural characters of Salmonella sp in inner content of laid eggs on selective media}

A total 45 laid eggs (5 eggs/farm) samples were collected from Salmonella infected 9 layer farms. Out of 9 farms 4 were positive and isolation rate was $44.4 \%$. In the present study, 4 Salmonella isolates were found from laid eggs (5 eggs/farm) content from respective 9 Salmonella infected farms and isolation rate was $44.4 \%$. The results corresponded with the findings of Haider (2009) while the author reported 95\% isolation rate of Salmonella organism from outer shell, $45 \%$ from inner shell, $35 \%$ from egg albumin and $50 \%$ from egg yolk. It can be concluded that, laid eggs content received contamination by Salmonella organism as a vertical transmission of Salmonellosis or/and contamination with the droppings of Salmonella infected layer birds. 


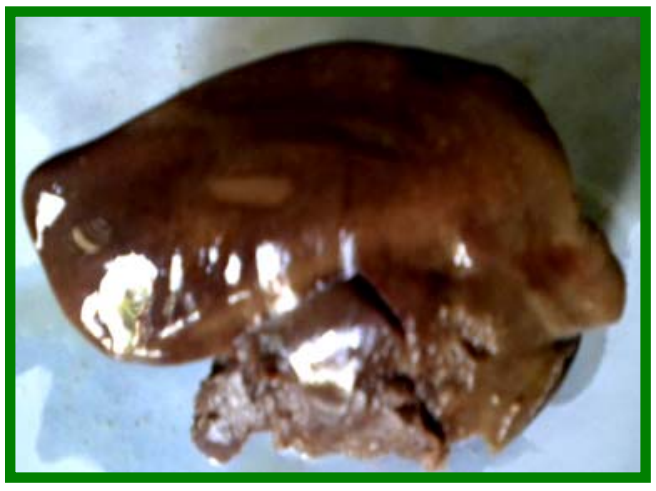

Fig. 1. The liver (farm no.10, sample no. 25) shows friable congestion and bronze discoloration with focal necrosis

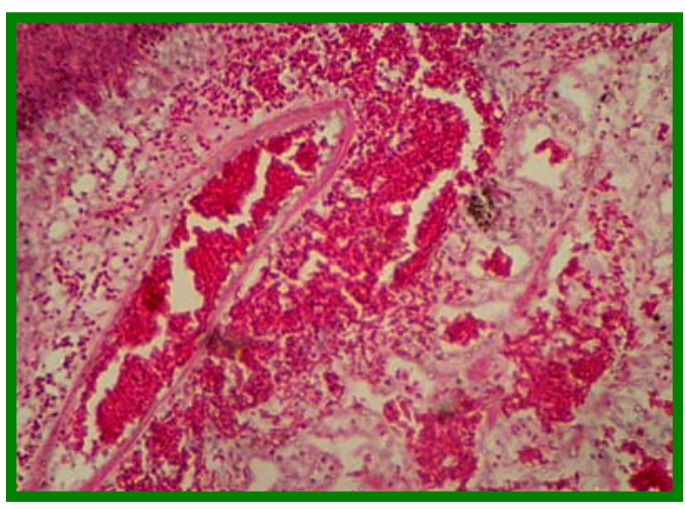

Fig. 3. Salmonella infected lung (farm no.1, tissue of sample no.3) shows sever congestion and pneumonia $(H$ \&E staining $X 83$ )

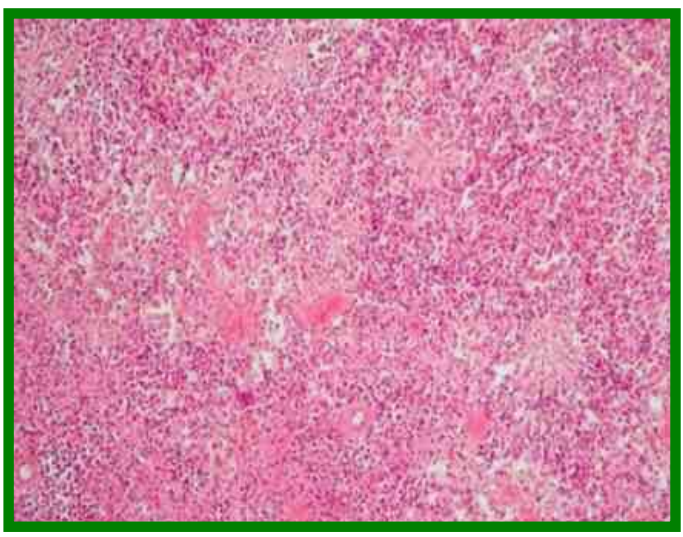

Fig. 5. Salmonella infected spleen (farm no.13, tissue of sample no.33) shows sever lymphocytic depletion and marked reticuloendothelial cell hyperplasia ( $\mathrm{H}$ \&E staining $X$ 83)

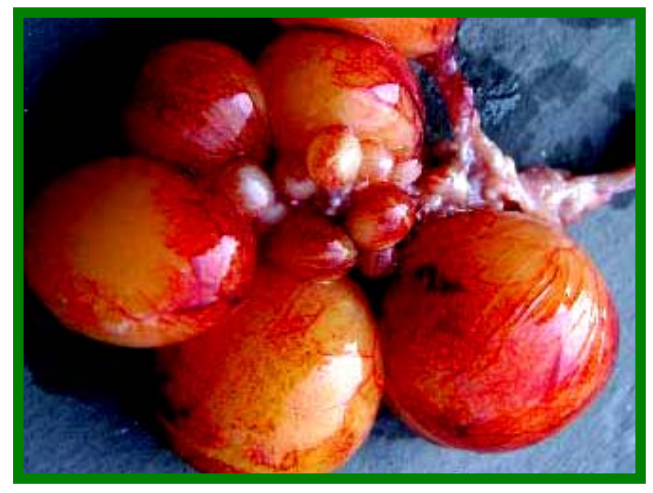

Fig. 2. Salmonella affected egg follicles (farm no.8, sample no.20) shows haemorrhagic, congested and discolored with stalk formation

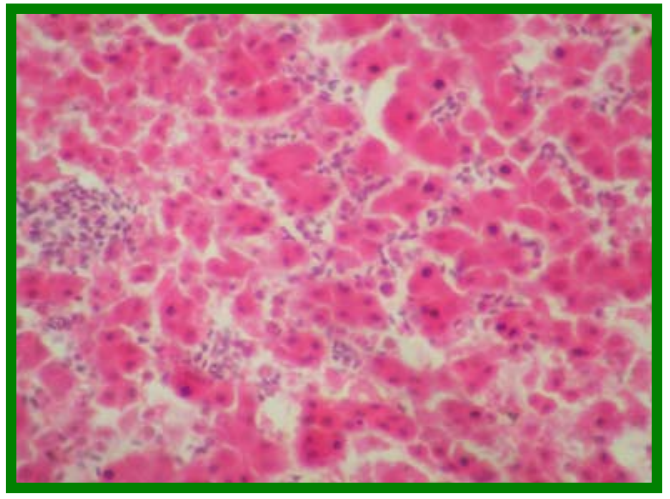

Fig. 4. Salmonella infected liver (farm no.8, tissue of sample no.20) shows multifocal nodule formation and infiltration of inflammatory cells ( $H$ \&E staining $X 333$ )

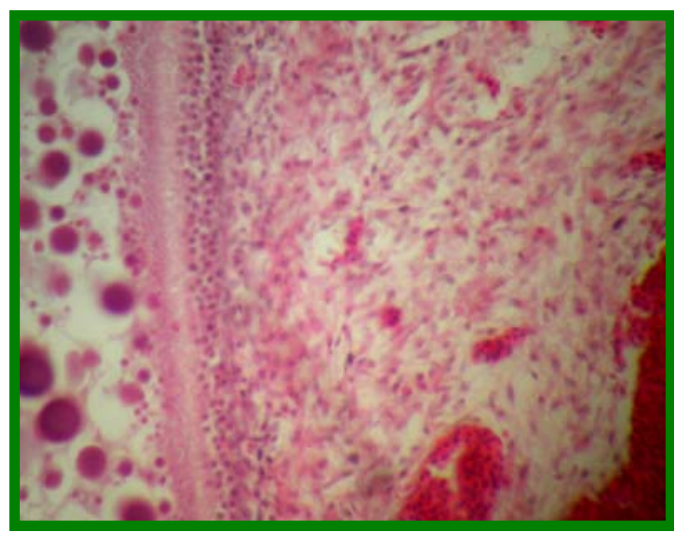

Fig. 6. Salmonella infected egg follicles (farm no.2, tissue of sample no.6) shows marked congestion and leukocytic infiltration (H \&E staining $X$ 83) 
Briefly, in the present investigation, $44.7 \%$ Salmonella positive cases were recorded from ovarian swabs in which, Salmonella Gallinarum, Salmonella Pullorum and Paratyphoid causing Salmonella were 70.6\%, $17.6 \%$ and $11.8 \%$, respectively. Variable gross lesions were found in Salmonella affected organs of birds. A total of $53 \%$ liver, $59 \%$ egg follicles and $70.6 \%$ intestine were affected in this study. Histologically, $76.5 \%$ liver, $82.4 \%$ egg follicles and $47.1 \%$ intestines revealed tissue changes with variation in birds. Salmonella isolation rate was $44.4 \%$ in laid eggs of Salmonella-affected farms indicating transovarian transmission in poultry Salmonellosis.

From the above findings, it may be concluded that Salmonellosis has emerged as one of the most serious problems having adverse effects on poultry. In future for the control of Salmonella infection in poultry, vaccine production and gene level study need to be performed in Bangladesh to save the poultry industry.

\section{References}

Ahmed, A.K.M., Islam, M.T., Haider, M.G. and Hossain, M.M. 2008. Seroprevalence and pathology of naturally infected Salmonellosis in poultry with isolation and identification of causal agents. J. Bangladesh Agril. Univ. 6 (2): 327-334.

Beyaz, L. and Kutsal, O. 2003. Pathological and immunohistochemical studies in experimental Salmonella Gallinarum infection (Fowl typhoid) in chickens. Ankara Uni. Vet. Fak. Der. 50: 219-227.

Buxton, A. and Fraser, G. 1977. Animal Microbiology. Vol. 1. Blackwell Scientific Publications, Oxford, London, Edinburgh, Melbourne. Pp 103-115.

Chishti, M.A., Khan, M.Z. and Irfan, M. 1985. Pathology of liver and spleen in avian Salmonellosis. Pak. Vet. J. 5: 157-160.

Christensen, J.P., Brown, D.J., Madsen, M., Olsen, J.E. and Bisgaard, M. 1996. Hatchery borne Salmonella enterica serover Thnnessee infections in broilers. Ph.D. thesis. Submitted to the Department of Veterinary Microbiology, the Royal Veterinary and Agricultural University, Copenhagen, Denmark.

Christensen, J.P., Olsen, J.E., Hansen, H.C. and Bisgaard, M. 1992. Characterization of Salmonella enterica serovar Gallinarum biovars Gallinarum and Pullorum by plasmid profiling and biochemical analysis. Avian Pathol. 21: 461-470.

Clanek, B.W., Barnes, H.J., Beard, C.W., Mcdougald, L.R. and Saif, Y.M. 1991. Diseases of Poultry. $10^{\text {th }}$ edn. Iowa State University Press, Ames, USA. Pp 81-130.

Cown, S.T. 1985. Cown and Steel's Manual for the Identification of Medical Bacteria. $2^{\text {nd }}$ edn. Cambridge University Press, Cambridge, UK.

Deryck, D. and Pattron. 2004. Scientific status summary on bacteria associated with foodborne diseases and also related to public health significance of Salmonella in institute of food technologists, Chicago.

Deshmukh, S., Asrani, R.K., Ledoux, D.R., Rottinghaus, G.E., Bermudez, A.J. and Gupta, V.K. 2007. Pathologic changes in extrahepatic organs and agglutinin response to Salmonella Gallinarum infection in Japanese quail fed Fusarium verticillioides culture material containing known levels of fumonisin B1. Avian Dis. 51: 705-12.

Freeman, B.A. 1985. Burrow's Text Book of Microbiology. $22^{\text {nd }}$ edn. W. R. Saunders Company, London, UK. Pp $372-472$.

Gast, R.K. 1997. Paratyphoid Infections. In: Diseases of Poultry, Calnek, B.W., Barnes, H.J., Beard, C.W., McDoughald, L.R., and Saif, Y.M., (eds). 10th ED. lowa State University press. Ames, IA. Pp: 97-121.

Goswami, P., Chakraborti, A., Hui, A.K., Das, R., Sarkar, P. and Som, T.L. 2003. Isolation and identification of Salmonella Gallinarum form field cases and their antibiogram. Ind. Vet. Micro. J. 80: 184-185.

Habib-ur-Rehman, S., Sirzanin, Hamayun, K., Saleem, K., Nazir, A. and Bhatti, W.M. 2003. Incidence and gross pathology of Salmonellosis in chicken in Hyderabad. J. Asso. Vet. Advances. 2: 581-584.

Hafeji, Y.A., Shah, D.H., Joshi, B.P., Roy, A. and Prajapati, K.S. 2001. Experimental Pathology of field isolates of Salmonella Gallinarum in chickens. Ind. J. Poult. Sci. 36: 338-340.

Haider, M.G. 2009. Pathogenesis of pullorum disease in chickens. Ph D Dissertation, submitted to the Department of Pathology, Bangladesh Agricultural University, Mymensingh.

Haider, M.G., Hossain, M.G., Hossain, M.S., Chowdhury, E.H., Das, P.M. and Hossain, M.M. 2003. Isolation and characterization of enterobacteria associated with health and disease in Sonali chickens. Bang. J. Vet. Med. 2: 15-21.

Haque, M.E., Hamid, M.A., Howleder, M.A.R. and Haque, Q.M.E. 1991. Performance of native chicks and hens reared together or separately under rural condition in Bangladesh. Bangladesh Vet. 8: 11-13.

Holt, P.S., Vaughn, L.E., Moore, R.W. and Gast, R.K. 2006. Comparison of Salmonella enterica serovar Enteritidis levels in crops of fed or fasted infected hens. Avian Dis. 50: 425-9.

Hossain, M.A., Aalbaek, B., Christensen, J.P., Elisabeth, H., Islam, M.A. and Pankaj, K. 2003. Observations on experimental infection of Salmonella Gallinarum in Fayoumi and Hyline layer chickens. Bangladesh J. Progress. Agri. 14: 85-89. 
Humphrey, T.J., Baskerville, A., Mawer, S., Rowe, B. \& Hopper, S. 1989. Salmonella Enteritidis phage type 4 from the contents of intact eggs: a study involving naturally infected hens. Epidemiol. Infect. 103: 415-423.

Islam, M.M., Hossain, M.M., Haider, M.G., Chowdhury, E.H. and Kamruzzaman, M. 2006. Seroprevalence and pathological study of Salmonella infections in layer chickens and isolation of causal agents: In Proceedings of the $5^{\text {th }}$ International Poultry show and seminar from 01-03 march 2007, held in Bangladesh China Friendship Conference Centre (BCFCC), Sher-e-Bangla Nagar, Dhaka, Bangladesh. Pp 9-15.

Khan, M.A.H.N.A., Bari, A.S.M., Islam, M.R., Das, P.M. and Ali, M.Y. 1998. Pullorum disease in semimature chicks and its experimental pathology. Bangladesh Vet. J. 32: 124-128.

Kinde, H., Shivaprasad, H.L., Daft, B.M., Read, D.H., Ardans, A., Breitmeyer, R., Rajashekara, G., Nagaraja, K.V. and Gardner, I.A. 2000. Pathologic and bacteriologic findings in 27-week-old commercial laying hens experimentally infected with Salmonella Enteritidis, phage type 4. Avian Dis. 44: 239-48.

Luna, L. G. 1968. Manual of Histologic Staining Methods of the Armed Forces Institute of Pathology. $3^{\text {rd }}$ edn. McGraw Hill Book Co., New York, USA.

Merchant, I. A. and Packer, R. A. 1967. Veterinary Bacteriology and Virology. $7^{\text {th }}$ edn. The lowa State University Press, Ames, lowa, USA. Pp 211-306.

Msoffe, P.L.M., Minga, U.M., Mtambo, M.M.A., Gwakisa, P.S. and Olsen, J.E. 2006. Differences in resistance to Salmonella Enterica serovar Gallinarum infection among indigenous local chicken ecotypes in Tanzania. Avian Path. 35: 270-276.

OIE Manual, 2006. Salmonellosis. Office International des Epizooties. http:www.oie.int/chapter X.4.T.

Old DC. 1990. Salmonella. In: Topley \& Wilson's Principles of Bacteriology, Virology and Immunity. $8^{\text {th }}$ edn. Parker, M. T. and Duerden, B. I. (ed.). Vol. 2 Systematic Bacteriology. Edward Arnold. A division of Hodder \& Stoughton, London, UK.

Perez, C., Rivera, S., Pirela, A., Rincon, H., Mavarez, Y. and Roman, R. 2004. Isolation of Salmonella in poultry carcasses and evaluation of the effectiveness of different enrichment and selective media. Revist. Cientiflic. Facult. Genti. V. Univers. del Zulia. 14: 177-185.

Pomeroy, B.S. and Nagaraja, K.V. 1991. Fowl typhoid. In: Diseases of Poultry, 9th edn. B. W. Calnek, H. J. Barnes, C. W. Beard, W. M. Reid, and H. W. Yoder, Jr. eds. lowa State University Press, Ames, lowa. Pp 87-99.

Poppe, C., Johnson, R.P., Forsberg, C.M. \& Irwin, R.J. 1992. Salmonella Enteritidis and other Salmonella in laying hens and eggs from flocks with Salmonella in their environment. Can. J. vet. Res, 56: 226-232.

Prasanna, K. and Paliwal, O.P. 2003. Experimental fowl typhoid and pullorum disease in chickens, clinical and pathomorphological studies. Ind. J. Vet. Path. 26: 27-29.

Rahman, M.A., Samad, M.A., Rahman, M.B. and Kabir, S.M.L. 2004. Bacterio-pathological studies on Salmonellosis, colibacillosis and pasteurellosis in natural and experimental infections in chickens. Bangladesh J. Vet. Med. 2: 1-8.

Rahman, M.M., Chowdhury, TIMF, Rahman, M.M. and Hossain, WIMA. 1997. Survillance of Salmonella \& Escherichia organisms in poultry feed. Bangladesh Vet. J. 15: 59-62.

Rybolt, M.L., Wills, R.W. and Bailey, R.H. 2005. Use of secondary enrichment for isolation of Salmonella from naturally contaminated environmental samples. Poult. Sci. 84: 992-997.

Shane, S.M. 1989. The impact of infectious disease of poultry in selected African countries. In: Impact of Diseases on Livestock production in the Tropic. H. P. Riemann and M. J. Burridge (eds.). Elsevier, Amsterdam, Netherlands. Pp 277-285.

Sharma, M. and Katock, R.C. 1996. Deadly outbreak in chicks owing to Salmonella typhimurium. Indian J. Poultry Sci. 31: 60-62.

Shivaprashad, H.L. 1997. Pullorum disease and fowl typhoid. In: Diseases of Poultry, 10th ed.; Calnek, B.W., Barnes, H.J., Beard, C.W., McDoughald, L.R., Saif, Y.M., Eds.; lowa State University press: Ames, IA, USA. Pp 82-96.

Snoeyenbos, G.H. 1991. Pullorum disease. In: Calnek, B.W., Barnes, H.J., Beard. C.W. Reid, W.M. and Yoder, H.W. Jr. (eds). Diseases of Poultry. 9th ED (London, Wolfe publishing Ltd.). Pp 87-99

Sujatha, K., Dhanalakshmi, K. and Rao, A. S. 2003. Isolation and characterization of S. Gallinarum from chicken. Ind. Vet. J. 80 : 473-474.

Wigley, P., Berchieri, A. Jr., Page, K.L., Smith, A.L. and Barrow, P.A. 2001. Salmonella enterica serovar pullorum persists in splenic macrophages and in the reproductive tract during persistent, disease free carriage in chickens. Infect. Immun. 69: 78737879.

Yuno, M.M.L., Terzolo, H.R., Fernandez, H.D., Malena. R.C. and Altuna, M.E. 1995. Evaluation of selective culture media for isolation of Salmonella from poultry. Revista Argentina de Micro. 27: 57-69. 